\begin{tabular}{c} 
Volume and Issues Obtainable at Center for Sustainability Research and Consultancy \\
Journal of Accounting and Finance in Emerging Economies \\
ISSN: 2519-0318 ISSN (E) 2518-8488 \\
Volume 7: Issue 1 March 2021 \\
CSRᄃ \\
Journal homepage: www.publishing.globalcsrc.org/jafee \\
\hline
\end{tabular}

\title{
Deciphering the Global Private Financial Flows
}

\author{
${ }^{1}$ Muhammad Zeeshan Shaukat, ${ }^{2}$ Muhammad Aamir, ${ }^{3}$ Imad-ud-Din Akbar, ${ }^{4}$ Majid Ali
}

${ }^{1}$ Associate Professor, University of Central Punjab, Lahore, Pakistan, mz.shaukat@ucp.edu.pk

${ }^{2}$ Assistant Professor, Hailey College of Commerce, University of the Punjab, Lahore, Pakistan, aamir@hcc.edu.pk

${ }^{3}$ Assistant Professor, National University of Modern Languages Islamabad, Lahore Campus, Pakistan, dr.imad@ numl.edu.pk

${ }^{4}$ Assistant Professor, Hailey College of Commerce, University of the Punjab, Lahore, Pakistan, majid.hcc@pu.edu.pk

\begin{tabular}{l}
$\quad$ ARTICLE DETAILS \\
\hline History \\
Revised format: February \\
2021 \\
Available Online: March \\
2021 \\
\hline Keywords \\
Global, grey relational grade, \\
GRA, Pakistan, private \\
financial flows.
\end{tabular}

JEL Classification:

M40, M49

\section{ABSTRACT}

Cross border and inter country financial recourse is like a civilization hold. It is fundamentally important phenomenon to study. Purpose of this study is to investigate inter country global private financial flows in context of current financial regimes. Design of the study is quantitative based on a secondary data taken from website of World Development Indicators (WDI) 2020. A literature review of relevant studies extracted from renowned research databases is also integral part of the overall design of the study. For the purpose of analysis and investigation the study uses Grey Relational Analysis (GRA). GRA is a mathematical technique capable of handling a multitude of alternatives with plenty of criteria simultaneously. It is a ranking technique that generates the reference series, normalizes the data and compares the weighted average grey coefficients with reference series. GRA is a popular methodology espoused in grey systems theory. It is the study of eighty-three countries on the basis of five different criteria. The countries have been ranked according to Grey relational grades by using rank function of excel and are divided into seven different categories on the basis of intensity of financial flows. The categories have been made on the basis of ordinal scale e.g. exceptionally high level of private global financial flows, excellent, very good, good, fair, poor and very poor. Results show that China, Niger, Brazil, Mozambique, Mongolia, St. Vincent and the Grenadines, Cambodia, Grenada, Thailand, Indonesia, Argentina and Maldives have exceptionally high private financial flows, whereas, countries namely Lesotho, Kazakhstan, Uzbekistan, Botswana, Guatemala, Solomon Islands, Afghanistan, Bolivia, Bhutan, Angola and Russian Federation have poor financial flows. Majorly, Arabian Countries (AC), Organization for Economic Co-operation and Development (OECD) and Union of South American Nations (UNASUR) countries fall under exceptionally high ensign, whereas, member countries of Economic Cooperation Organization (ECO) and Southern Africa Development Community (SADC) countries fall under very poor ensign. This study is useful for political governments, international agencies, researchers and academia 
(students and teachers of international finance). It also provides new information and deeper insights by way of assigning grey relational grades to countries and classifies them into seven groups. It also extends discussion to enlighten upon bloc level position.

(C) 2021 The authors, under a Creative Commons Attribution-

NonCommercial 4.0

Corresponding author's email address: mz.shaukat@ucp.edu.pk

Recommended citation: Shaukat, M. Z., Aamir, M., Akbar, I. D. \& Ali, M. (2021). Deciphering the Global Private Financial Flows. Journal of Accounting and Finance in Emerging Economies, 7(1),233240

\section{Introduction}

Global private financial flows are recognition of a country's ensuing transparency, accountability, policy credibility, confidence building, regulatory and supervisory arrangements, and stability of economic environment and strength of monetary systems. This stream of financial flows is extremely important for a country and considered as a hall mark of economic development. Private financial flows are appendage to the financial resources of an economy. It is current and hot topic being researched by the management scientists and economists. There is plenty of existing literature in this behalf that accounts for variety of aspects global private financial flows and uses different techniques/ methodologies viz: Bazilian et al. (2011) carried a comprehensive research on estimation of power sectors' macro financial flows of developing countries and provided evidence to improve decision/policy making for energy poverty. Binici et al. (2010) concluded that capital controls have impact on composition and volume of capital flows; particularly, equity and debt controls markedly decreases outflows.

Cova and Natoli (2020) claimed that during global financial crises foreign financial flows were playing a key role. Carnevali et al. (2020) proposed a model to investigate financial flows, ecosystem \& society and economy and found that there is significant role of cross-border financial flows in economic growth. Literature is rich on global private financial flows but still there is dearth of country level comparative studies. It is an ever green research area and there is always a room for further research. The importance, sufficiency, patterns and benefits of global private financial flows for a country can only be understood in contrast with that of its rivals. In view of the above representation the problem of research is construed as need of country level analysis of private financial flows. Objective of this research is to decipher the global private financial flows of eighty three countries. There are numerous methodological options available in literature that have clear based on econometric, statistical and mathematical models. Wide array of methodological options was considered to achieve objective of the study. Grey Relational Analysis (GRA) is opted as a research methodology. GRA is methodology that is espoused in grey systems theory and this methodology is capable of accommodating wide variety of variables pertaining to a multitude of cross-sections. Rest of the paper is arranged into survey of literature, research design \& method, results \& discussion and concluding remarks.

\section{Survey of Literature}

In order to set out set of the study a survey of contemporary literature has been conducted by exploring the databases like Wiley-Blackwell, Taylor \& Francis, Springer Link, Emerald, Elsevier (Science Direct) and Ebrary. Relevant literature is reported here to espouse the study within the current literature. Anwar and Cooray (2015) buttressed that official development and government spending plans indirectly impact on per capita income; whereas, foreign direct investment and remittances directly impact on income per capita. Bayoumi et al. (2015) proclaimed that extent of capital substantially affect net official flows that impact on current account balances. Cavallaro and Cutrini (2019) analyzed emerging economies' cross-border bank flows and claimed that global precariousness magnifies demand for institutional quality which suggested emerging economies having feeble institutional settings that are 
open to capital retrenchments. Combes et al. (2019) argued that financial flows have substantial direct and indirect effect on economic growth. Dieleman et al. (2016) affirmed that HIV/AIDS, tuberculosis, DAH and Malaria have significant effect on health systems of low income countries that envisages coordination and cooperation in terms of international financial flows for health. Glomsrød and Wei (2018) stated that green financing has gained reasonable importance that reflects higher GDP, decreases coal consumption, shifting capital owners' income to wage earners and increase in non-fossil electricity consumption. Guthrie et al (2015) claimed that it is call of the day to enhance track immunization financial flows to improve performance, accountability and sustainability. Hobza and Zeugner (2014) emphasized that financial inter-linkages play a pertinent role in bilateral financial flows stocks and data transmission. Lim and Mohapatra (2016) buttressed that heterogeneity across different types of financial flows and portfolio flows (particularly bond) tend to be more subtle than foreign direct investment to quantitative easing. Obstfeld (2012) highlighted that global current account imbalances impact on financial flows which imitates in macroeconomics. Young and Tackett (2018) stated that there is a negative relationship between economic flows and labor relations; and a positive relationship between social globalization and labor relations. These studies have used wide range different datasets and different methodologies to reach to these conclusions but a study addressing directly the issue in hand could not be found. Theoretical foundations of this study can be supported from the framework of World Bank.

\section{Theoretical Foundations}

This study is theoretically espoused in the framework of World Development Indicators (WDI), 2020). The variables used to evaluate the global private financial flow have been adopted from WDI (2020). There are five variables used in this study to viz: 1) equity flows in form of foreign direct investment (net inflows in million US Dollars) having 'larger is the best characteristic', 2) equity flows in form of foreign direct investment (net inflows in \% of GDP) having 'larger is the best characteristic', 3) equity flows in form of portfolio (equity in million US Dollars) having 'larger is the best characteristic', 4) debt flows in form of bonds (in million US Dollars) having 'larger is the best characteristic' and 5) debt flows in form of commercial bank and other lending (in million US Dollars) having 'larger is the best characteristic'.

\section{Research Design and Method}

It is a quantitative research study that follows deductive approach. Design of the research study includes survey of literature, secondary data extraction and mathematical analysis. Method used in this research is Grey Relational Analysis (GRA). The country level data has been obtained from World Development Indicators (WDI), 2020. Population under study is eighty three countries. Unit of analysis is country and economic bloc. GRA is a unique mathematical method from within the multitude of multi-criteriadecision-making techniques. It has privileges over statistical techniques (Hamzaçebi \& Pekkaya, 2011; Kuo et al., 2008; Tayyar et al., 2014; Wu, 2002; Zhang et al., 2011). Analysis under this method progresses stepwise. The stepwise procedure, formulas, notations have been adopted from Qazi et al., (2020) and (Ertuğrul, et al. 2016).

Step 1: Created a data set and established decision matrix (1).

$$
x_{i}(k)=\left[\begin{array}{ccc}
x_{1}(1) x_{1}(2) & \cdots & x_{1}(m) \\
\vdots & \ddots & \vdots \\
x_{n}(1) x_{n}(2) & \cdots & x_{n}(m)
\end{array}\right]
$$

Table 1: Original Dataset of Global Private Financial Flows

\begin{tabular}{clccccc}
\hline Sr. & Country & $\mathbf{1}$ & $\mathbf{2}$ & $\mathbf{3}$ & $\mathbf{4}$ & $\mathbf{5}$ \\
\hline $\mathbf{1}$ & Afghanistan & 119 & 0.6 & 0 & 0 & -5 \\
$\mathbf{2}$ & Albania & 1,204 & 8 & -3 & 340 & -130 \\
$\ldots$ & $\ldots \ldots \ldots .$. & $\ldots$ & $\ldots$ & $\ldots$ & $\ldots$ & $\ldots$ \\
$\ldots$ & $\ldots \ldots \ldots .$. & $\ldots$ & $\ldots$ & $\ldots$ & $\ldots$ & $\ldots$ \\
\hline
\end{tabular}




\begin{tabular}{clccccc}
\hline $\mathbf{5 8}$ & Pakistan & 2,354 & 0.7 & -528 & 0 & 1,596 \\
$\mathbf{5 9}$ & Peru & 6,488 & 2.9 & -442 & $-1,077$ & 455 \\
$\ldots$ & $\ldots \ldots \ldots \ldots$ & $\ldots$ & $\ldots$ & $\ldots$ & $\ldots$ & $\ldots$ \\
$\ldots .$. & $\ldots \ldots \ldots .$. & $\ldots$ & $\ldots$ & $\ldots$ & $\ldots$ & $\ldots$ \\
$\mathbf{8 2}$ & Uzbekistan & 625 & 1.2 & 13 & 0 & -51 \\
$\mathbf{8 3}$ & Zambia & 408 & 1.5 & -5 & 0 & 1,495 \\
\hline \multicolumn{5}{c}{ Source of Data: World Development Indicators (WDI), 2020) }
\end{tabular}

Step 2: Generated reference series and comparison matrix (2)

$$
x_{0}=\left[x_{0}(k) \ldots \ldots \ldots \ldots x_{0}(n)\right]
$$

Table 2: Reference and Comparable Sequences

\begin{tabular}{clccccc}
\hline Sr. & \multicolumn{1}{c}{ Country } & $\mathbf{1}$ & $\mathbf{2}$ & $\mathbf{3}$ & $\mathbf{4}$ & $\mathbf{5}$ \\
\hline $\mathbf{0}$ & Reference Sequence & 203492 & 21.5 & 60668 & 68614 & 29749 \\
$\mathbf{1}$ & Afghanistan & 119 & 0.6 & 0 & 0 & -5 \\
$\mathbf{2}$ & Albania & 1,204 & 8 & -3 & 340 & -130 \\
$\ldots$ & $\ldots \ldots \ldots \ldots .$. & $\ldots$ & $\ldots$ & $\ldots$ & $\ldots$ & $\ldots$ \\
$\ldots$. & $\ldots \ldots \ldots .$. & $\ldots$ & $\ldots$ & $\ldots$ & $\ldots$ & $\ldots$ \\
$\mathbf{5 8}$ & Pakistan & 2,354 & 0.7 & -528 & 0 & 1,596 \\
$\mathbf{5 9}$ & Peru & 6,488 & 2.9 & -442 & $-1,077$ & 455 \\
$\ldots$ & $\ldots \ldots \ldots \ldots$. & $\ldots$ & $\ldots$ & $\ldots$ & $\ldots$ & $\ldots$ \\
$\ldots$ & $\ldots \ldots \ldots .$. & $\ldots$ & $\ldots$ & $\ldots$ & $\ldots$ & $\ldots$ \\
$\mathbf{8 2}$ & Uzbekistan & 625 & 1.2 & 13 & 0 & -51 \\
$\mathbf{8 3}$ & Zambia & 408 & 1.5 & -5 & 0 & 1,495 \\
\hline
\end{tabular}

Step 3: Normalized the matrix for larger the better (3).

$$
x_{i}^{*}(k)=\frac{x_{i}^{(0)}(k)-\min x_{i}^{(0)}(k)}{\max x_{i}^{(o)}(k)-\min x_{i}^{(o)}(k)}
$$

Table 3: Normalized Matrix

\begin{tabular}{clccccc}
\hline Sr. & \multicolumn{1}{c}{ Country } & $\mathbf{1}$ & $\mathbf{2}$ & $\mathbf{3}$ & $\mathbf{4}$ & $\mathbf{5}$ \\
\hline $\mathbf{0}$ & Reference Sequence & 1.0000 & 1.0000 & 1.0000 & 1.0000 & 1.0000 \\
$\mathbf{1}$ & Afghanistan & 0.0280 & 0.2230 & 0.1048 & 0.1093 & 0.6521 \\
$\mathbf{2}$ & Albania & 0.0332 & 0.4981 & 0.1047 & 0.1137 & 0.6506 \\
$\ldots$ & $\ldots \ldots \ldots$. & $\ldots$ & $\ldots$ & $\ldots$ & $\ldots$ & $\ldots$ \\
$\ldots$ & $\ldots \ldots \ldots$. & $\ldots$ & $\ldots$ & $\ldots$ & $\ldots$ & $\ldots$ \\
$\mathbf{5 8}$ & Pakistan & 0.0386 & 0.2268 & 0.0970 & 0.1093 & 0.6708 \\
$\mathbf{5 9}$ & Peru & 0.0584 & 0.3086 & 0.0983 & 0.0953 & 0.6574 \\
$\ldots$ & $\ldots \ldots \ldots$. & $\ldots$ & $\ldots$ & $\ldots$ & $\ldots$ & $\ldots$ \\
$\ldots$ & $\ldots \ldots \ldots$. & $\ldots$ & $\ldots$ & $\ldots$ & $\ldots$ & $\ldots$ \\
$\mathbf{8 2}$ & Uzbekistan & 0.0304 & 0.2454 & 0.1050 & 0.1093 & 0.6515 \\
$\mathbf{8 3}$ & Zambia & 0.0293 & 0.2565 & 0.1047 & 0.1093 & 0.6696 \\
\hline
\end{tabular}

Step 4: Computed deviation sequence (4), (5) and (6)

$$
\Delta_{0 i}(k)=\left|x_{0}^{*}(k)-x_{i}^{*}(k)\right|
$$

For biggest deviation:

For smallest deviation:

$$
\Delta_{\max }=\max _{\forall j \varepsilon i} \max _{\forall k}\left|x_{0}^{*}(k)-x_{j}^{*}(k)\right|
$$

$$
\Delta_{\min }=\min _{\forall j \varepsilon i} \min _{\forall k}\left|x_{0}^{*}(k)-x_{j}^{*}(k)\right|
$$

Table 4: Deviation Sequences

\begin{tabular}{lllllll}
\hline Sr. & Country & 1 & 2 & 3 & 4 & 5 \\
\hline
\end{tabular}




\begin{tabular}{|c|c|c|c|c|c|c|}
\hline $\mathbf{0}$ & Reference Sequence & 0.0000 & 0.0000 & 0.0000 & 0.0000 & 0.0000 \\
\hline 1 & Afghanistan & 0.9720 & 0.7770 & 0.8952 & 0.8907 & 0.3479 \\
\hline 2 & Albania & 0.9668 & 0.5019 & 0.8953 & 0.8863 & 0.3494 \\
\hline ... & ........... & $\cdots$ & $\cdots$ & $\cdots$ & $\cdots$ & $\cdots$ \\
\hline ... & .......... & $\cdots$ & $\cdots$ & $\ldots$ & $\cdots$ & $\cdots$ \\
\hline 58 & Pakistan & 0.9614 & 0.7732 & 0.9030 & 0.8907 & 0.3292 \\
\hline 59 & Peru & 0.9416 & 0.6914 & 0.9017 & 0.9047 & 0.3426 \\
\hline$\cdots$ & ........... & $\cdots$ & $\cdots$ & $\cdots$ & $\cdots$ & $\cdots$ \\
\hline$\cdots$ & ........... & $\ldots$ & $\ldots$ & $\ldots$ & $\ldots$ & $\ldots$ \\
\hline 82 & Uzbekistan & 0.9696 & 0.7546 & 0.8950 & 0.8907 & 0.3485 \\
\hline 83 & Zambia & 0.9707 & 0.7435 & 0.8953 & 0.8907 & 0.3304 \\
\hline
\end{tabular}

Step 5: Computed grey relational co-efficient (7) using $0.5(\xi)$ as distinguishing co-efficient between 0 and 1.

$$
\gamma\left[x_{0}^{*}(k), x_{i}^{*}(k)\right]=\frac{\Delta_{\min }+\xi \Delta_{\max }}{x_{0 i}(k)+\xi \Delta_{\max }}, 0<\gamma\left[x_{o}^{*}(k), x_{i}^{*}(k)\right] \leq 1
$$

Table 5: Grey Relational Co-efficient

\begin{tabular}{clccccc}
\hline Sr. & \multicolumn{1}{c}{ Country } & $\mathbf{1}$ & $\mathbf{2}$ & $\mathbf{3}$ & $\mathbf{4}$ & $\mathbf{5}$ \\
\hline $\mathbf{0}$ & Reference Sequence & 1.0000 & 1.0000 & 1.0000 & 1.0000 & 1.0000 \\
$\mathbf{1}$ & Afghanistan & 0.3397 & 0.3916 & 0.3584 & 0.3595 & 0.5897 \\
$\mathbf{2}$ & Albania & 0.3409 & 0.4991 & 0.3584 & 0.3607 & 0.5886 \\
$\ldots \ldots$ & $\ldots \ldots \ldots \ldots$ & $\ldots$ & $\ldots$ & $\ldots$ & $\ldots$ & $\ldots$ \\
$\ldots \ldots$ & $\ldots \ldots \ldots$. & $\ldots \ldots$ & $\ldots$ & $\ldots$ & $\ldots$ & $\ldots$ \\
$\mathbf{5 8}$ & Pakistan & 0.3421 & 0.3927 & 0.3564 & 0.3595 & 0.6030 \\
$\mathbf{5 9}$ & Peru & 0.3468 & 0.4197 & 0.3567 & 0.3559 & 0.5934 \\
$\ldots$ & $\ldots \ldots \ldots \ldots$ & $\ldots \ldots$ & $\ldots$ & $\ldots$ & $\ldots$ & $\ldots$ \\
$\ldots$ & $\ldots \ldots \ldots$ & $\ldots$. & $\ldots$ & $\ldots$ & $\ldots$ & $\ldots$ \\
$\mathbf{8 2}$ & Uzbekistan & 0.3402 & 0.3985 & 0.3584 & 0.3595 & 0.5893 \\
$\mathbf{8 3}$ & Zambia & 0.3400 & 0.4021 & 0.3583 & 0.3595 & 0.6021 \\
\hline
\end{tabular}

Step 6: Computed weighted sum of grey relational co-efficient i.e. Grey Relational Grade (8) and (9).Equal weight has been used for variables i.e. 1 divided by number of variables.

$$
\begin{aligned}
& \gamma\left(x_{0}^{*}, x_{i}^{*}\right)=\sum_{k=1}^{n} \beta_{k} \gamma\left[x_{0}^{*}(k), x_{i}^{*}(k)\right] \\
& \sum_{k=1}^{n} \beta_{k}=1
\end{aligned}
$$

Table 6: Grey Relational Grades (GRG)

\begin{tabular}{clc}
\hline Sr. & \multicolumn{1}{c}{ Country } & GRG \\
\hline $\mathbf{0}$ & Reference Sequence & 1.0000 \\
$\mathbf{1}$ & Afghanistan & 0.4078 \\
$\mathbf{2}$ & Albania & 0.4295 \\
$\ldots$ & $\ldots \ldots \ldots \ldots$. & $\ldots$ \\
$\ldots$ & $\ldots \ldots \ldots .$. & $\ldots$ \\
$\mathbf{5 8}$ & Pakistan & 0.4107 \\
$\mathbf{5 9}$ & Peru & 0.4145 \\
$\ldots$ & $\ldots \ldots \ldots \ldots$. & $\ldots$ \\
$\ldots$ & $\ldots \ldots \ldots \ldots$ & $\ldots .$. \\
$\mathbf{8 2}$ & Uzbekistan & 0.4092 \\
$\mathbf{8 3}$ & Zambia & 0.4124 \\
\hline
\end{tabular}

\section{Results and Discussion}

Results of GRA are presented in Table 7. Results of GRA are clustered into groups against ensigns to make the results GRA more meaningful, understandable, interpretable and comparable. The scheme of ensigns entails as: Exceptionally High (countries having grey relational grade ranging from 0.4379 to 0.8017 are considered as countries having exceptionally high private financial inflows), Excellent (countries having grey relational grade ranging from 0.4211 to 0.4333 are considered having excellent 
private financial inflows), Very Good (countries having grey relational grade ranging from 0.4156 to 0.4208 are considered as having very good private financial inflows), Good (countries having grey relational grade ranging from 0.4135 to 0.4151 are considered having good private financial inflows). Fair (countries having grey relational grade ranging from 0.4120 to 0.4133 are considered reasonable private financial inflows), Poor (countries having grey relational grade ranging from 0.4105 to 0.4117 are considered poor private financial inflows) and Very Poor (countries having grey relational grade ranging from 0.3522 to 0.4096 are considered as countries having very poor private financial inflows).

Table 7: Results of Grey Relational Analysis

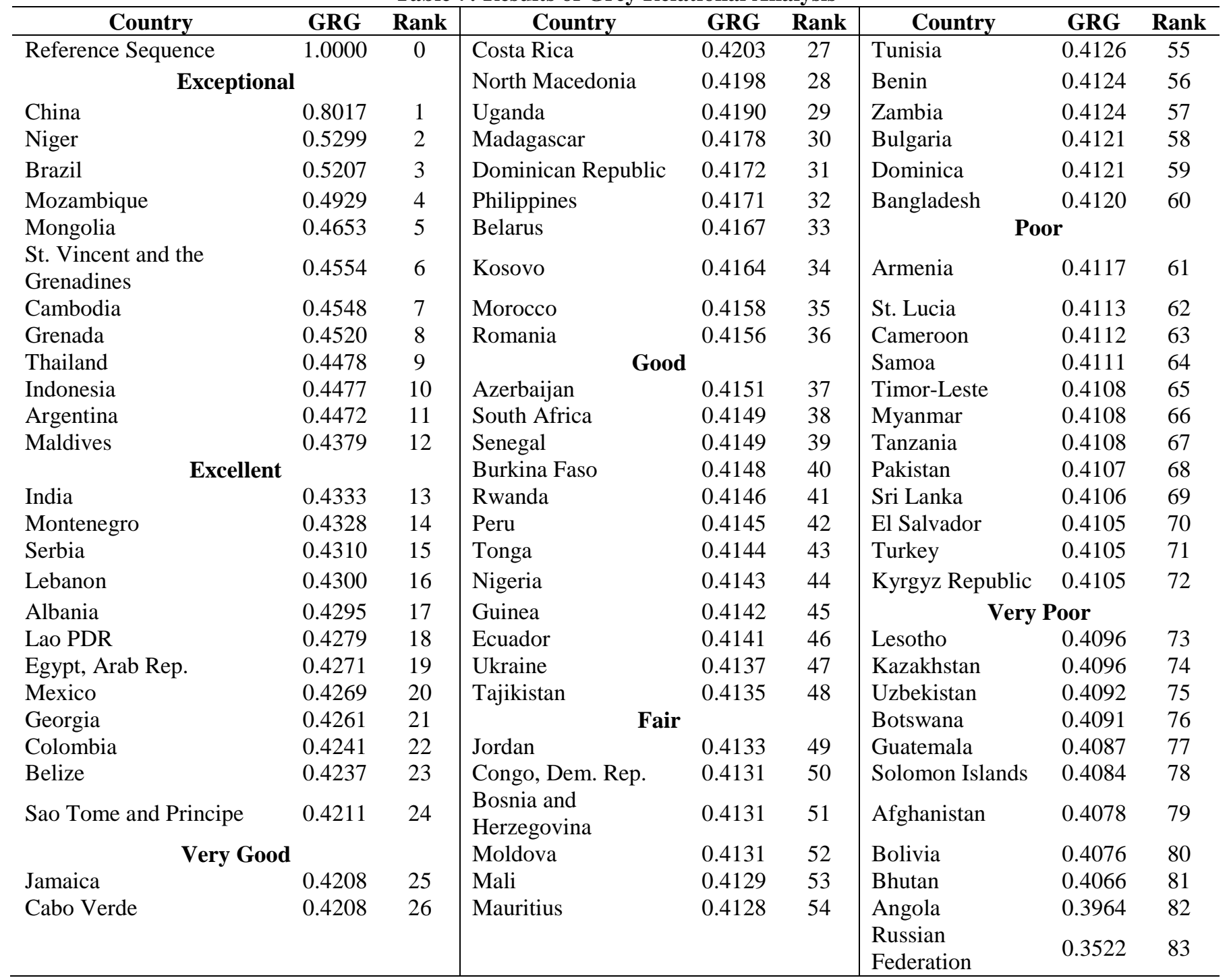

China, Niger, Brazil, Mozambique, Mongolia, St. Vincent, Grenadines, Cambodia, Grenada, Thailand, Indonesia, Argentina and Maldives are the countries having exceptionally high GRG ranks. India, Montenegro, Serbia, Lebanon, Albania, Lao PDR, Egypt, Arab Representative, Mexico, Georgia, Colombia, Belize, and Sao Tome and Principe have excellent GRG ranks. But the range of countries having very Good rank is: Jamaica, Cabo Verde, Costa Rica, North Macedonia, Uganda, Madagascar, Dominican Republic, Philippines, Belarus, Kosovo, Morocco and Romania. Likewise, countries having good GRG \& rank are Azerbaijan, South Africa, Senegal, Burkina Faso, Rwanda, Peru, Tonga, Nigeria, Guinea, Ecuador, Ukraine and Tajikistan. The fair rank category includes countries such as Jordan, Congo, Dem, Rep, Bosnia, and Herzegovina, Moldova, Mali, Mauritius, Tunisia, Benin, Zambia, Bulgaria, Dominica and Bangladesh. Correspondingly, poor rank includes countries are such as Armenia, St. Lucia, Cameroon, Samoa, Timor-Leste, Myanmar, Tanzania, Pakistan, Sri Lanka, El Salvador, Turkey and Kyrgyz Republic and very poor rank includes countries like Lesotho, Kazakhstan, 238 
Uzbekistan, Botswana, Guatemala, Solomon Islands, Afghanistan, Bolivia, Bhutan, Angola and Russian Federation. Majorly, Arabian Countries (AC), Organization for Economic Co-operation and Development (OECD) and Union of South American Nations (UNASUR) countries fall under exceptionally high ensign, whereas, member countries of Economic Cooperation Organization (ECO) and Southern Africa Development Community (SADC) countries fall under very poor ensign.

\section{Concluding Remarks}

Global private financial flows are a vital phenomenon to be investigated at country levels. It has fundamental importance for a country to stabilize its economy. This study, therefore, has opted to investigate the subject phenomenon. It uses quantitative deductive approach and applies GRA on a country level secondary data. The data has obtained from WDI 2020 and countries having included in investigation on the basis of availability of data. Findings of the study show that China, Niger, Brazil, Mozambique, Mongolia, St. Vincent, Grenadines, Cambodia, Grenada, Thailand, Indonesia, Argentina and Maldives are the countries having exceptionally high GRG and rank. Whereas Lesotho, Kazakhstan, Uzbekistan, Botswana, Guatemala, Solomon Islands, Afghanistan, Bolivia, Bhutan, Angola and Russian Federation are the countries having very low GRG \& rank consequently have very poor private financial flows. The other countries fall within the bracket of exceptionally high and very poor. If we talk of bloc level results, it can be observed that majorly Arabian Countries (AC), Organization for Economic Cooperation and Development (OECD) and Union of South American Nations (UNASUR) countries fall under exceptionally high ensign, whereas, member countries of Economic Cooperation Organization (ECO) and Southern Africa Development Community (SADC) countries fall under very poor ensign. This study contributes into the literature grey relational co-efficient, grey relational grades, country level and bloc level discussion. This study has theoretical and practical implications for political governments, researchers and international institutions. This study also has certain limitations i.e. it is secondary database study and data has been elicited from WDI 2020 therefore, the results can be generalized accordingly and it is recommended that future researchers should build their studies on different datasets. There are other ranking techniques available in literature we have used GRA therefore it is suggested to use some methodology to validate the results. Scheme of equal weights to evaluate the variables compositely has been employed this combination can also be rationalized on the basis of some other method like Entropy, AHP etc.

\section{References}

Anwar, S., \& Cooray, A. (2015). Financial flows and per capita income in developing countries. International Review of Economics \& Finance, 35, 304-314.

Bayoumi, T., Gagnon, J., \& Saborowski, C. (2015). Official financial flows, capital mobility, and global imbalances. Journal of International Money and Finance, 52, 146-174.

Bazilian, M., Nussbaumer, P., Gualberti, G., Haites, E., Levi, M., Siegel, J., ... \& Fenhann, J. (2011). Informing the financing of universal energy access: An assessment of current financial flows. The Electricity Journal, 24(7), 57-82.

Binici, M., Hutchison, M., \& Schindler, M. (2010). Controlling capital? Legal restrictions and the asset composition of international financial flows. Journal of International Money and Finance, 29(4), 666-684.

Carnevali, E., Deleidi, M., Pariboni, R., \& Passarella, M. V. (2020). Cross-border financial flows and global warming in a two-area ecological SFC model. Socio-Economic Planning Sciences, 100819.

Cavallaro, E., \& Cutrini, E. (2019). Distance and beyond: What drives financial flows to emerging economies? Economic Modelling, 81, 533-550.

Combes, J. L., Kinda, T., Ouedraogo, R., \& Plane, P. (2019). Financial flows and economic growth in developing countries. Economic Modelling, 83, 195-209.

Cova, P., \& Natoli, F. (2020). The risk-taking channel of international financial flows. Journal of International Money and Finance, 102, 102096.

Dieleman, J. L., Schneider, M. T., Haakenstad, A., Singh, L., Sadat, N., Birger, M., ... \& Murray, C. J. 
(2016). Development assistance for health: past trends, associations, and the future of international financial flows for health. The Lancet, 387(10037), 2536-2544.

Ertuğrul, İ., Öztaş, T., Özçil, A., \& Öztaş, G. Z. (2016). Grey relational analysis approach in academic performance comparison of university a case study of Turkish universities. European Scientific Journal, Special Edition, 128-139.

Glomsrød, S., \& Wei, T. (2018). Business as unusual: the implications of fossil divestment and green bonds for financial flows, economic growth and energy market. Energy for sustainable development, 44, 1-10.

Guthrie, T., Zikusooka, C., Kwesiga, B., Abewe, C., Lagony, S., Schutte, C., ... \& Brenzel, L. (2015). Mapping financial flows for immunisation in Uganda 2009/10 and 2010/11: new insights for methodologies and policy. Vaccine, 33, A79-A84.

Hamzaçebi, C., \& Pekkaya, M. (2011). Determining of stock investments with grey relational analysis. Expert Systems with Applications, 38(8), 9186-9195.

Hobza, A., \& Zeugner, S. (2014). Current accounts and financial flows in the euro area. Journal of International Money and Finance, 48, 291-313.

Kuo, Y., Yang, T., \& Huang, G. W. (2008). The use of grey relational analysis in solving multiple attribute decision-making problems. Computers \& industrial engineering, 55(1), 80-93.

Lim, J. J., \& Mohapatra, S. (2016). Quantitative easing and the post-crisis surge in financial flows to developing countries. Journal of International Money and Finance, 68, 331-357.

Obstfeld, M. (2012). Financial flows, financial crises, and global imbalances. Journal of International Money and Finance, 31(3), 469-480.

Qazi, T. F., Basit, A., Asghar, W. \& Niazi, A. A. K. (2020). Composite appraisal of women development in selected thirty-six countries with special focus on Pakistan: Applying grey incidence analysis model. Journal of Business and Social Review in Emerging Economies, 6(4), 1227-1236.

Tayyar, N., Akcanlı, F., Genç, E., \& Erem, I. (2014).Evaluating the financial performance of companies operating in the field of informatics and technology registered in BIST by analytical hierarchy process (AHP) and gray relational analysis (TIA) method. Accounting and Finance Journal, 61, 19-40.

World Development Indicators. (2020). Retrieved April 15, 2020, from http://wdi.worldbank.org/tables

$\mathrm{Wu}, \mathrm{H} . \mathrm{H}$. (2002). A comparative study of using grey relational analysis in multiple attribute decision making problems. Quality Engineering, 15(2), 209-217.

Young, A. T., \& Tackett, M. Y. (2018). Globalization and the decline in labor shares: Exploring the relationship beyond trade and financial flows. European Journal of Political Economy, 52, 18-35.

Zhang, S. F., Liu, S. Y., \& Zhai, R. H. (2011). An extended GRA method for MCDM with intervalvalued triangular fuzzy assessments and unknown weights. Computers \& Industrial Engineering, 61(4), 1336-1341. 